DOI: $10.24234 /$ se.v5i1.283

\title{
SCHOOL COUNSELLING SYSTEM IN THE CZECH REPUBLIC
}

\author{
AUTHOR'S DATA \\ Marcela Ehlová, Ph.D., Senior Lecturer \\ Faculty of Arts and Philosophy, Department of Education, \\ The University of Pardubice, Czech Republic \\ Contacts: marcela.ehlova@upce.cz
}

\begin{abstract}
The article deals with the issue of school counselling in the Czech Republic. It informs about the activities of the school counselling centre and characterizes the work of educational advisers, school prevention specialists, school psychologists and special school educators in contemporary schools. In conclusion, current trends are outlined that lead to the professionalization of school counselling and ensure better conditions for the education of pupils with special educational needs.
\end{abstract}

Keywords: school counselling, educational advisers, school prevention specialists, school psychologists, special school educators, students with special educational needs

\section{INTRODUCTION}

The school usually reflects the society in which it is currently located, with values and principles projected therein, on which people in the community not only base their views but the problems that the society experiences as well.

The current period is characterized as hasty, hectic, disparaging moral values and unfeeling towards children and young people are often perceived by the community as problematic. The adverse phenomena of the contemporary society affect all areas of life, including education. The changing society affects people's attitudes, reflects logically in the functioning of school institutions, thereby affecting the change in the life of the school and work of their actors. The school, being educational in its main features, has a large area of action.

Ever-increasing requirements to educate professionals and instill human values are set for teachers. They complete the school curriculum, they are forced to keep pace e.g. with 
technical advances, but they also have to deal with groups and individuals where there is a higher risk of undesirable behaviour - truancy, bullying, aggressive behaviour, vandalism, substance abuse, etc. or the so-called risk behaviour. We are troubled by the liberal approach to these pathological manifestations, where the underestimation of the impact of, for example, computer games, alcohol drinking and the growing influence of the media is a major trigger for a wide range of pathological behaviour and has a significant impact on the attitudes of young people to education and solutions to everyday problems.

We know very well that all these undesirable behaviours affect not only the education of students, but also the working conditions for teachers, professional workload of educators, demands on expertise as well as personal characteristics of teachers. There is an increased pressure on the creation of new jobs in schools (besides the teacher, it is the guidance counsellor, school prevention specialist, school psychologist, special education teacher, personal assistant, teacher's assistant, etc.). There are voices that emphasize the involvement of social educators in schools in order to expand the cooperation limits with the family. All of these experts are supposed to assist with behavioural and educational problems of pupils, in which the teacher is either not specialized, or simply not capable to deal with. The ideal situation, when there is working cooperation and coordination between all of the above positions in the school, i.e. the so-called school counselling office, is rather fiction in the current elementary and secondary schools. The aim of this paper is to offer readers a picture of school guidance of counsellors' activities at schools in the Czech Republic and point out some deficiencies and significant changes that should lead to the professionalization of school counselling.

\section{COUNSELLING SYSTEM IN CZECH REPUBLIC}

In the Czech Republic, there are several counselling systems at work. Social functions, tasks, content, forms and methods of work of various counselling bodies differ in terms of the range of issues and problems they help to solve.

The first of these falls under the province of the Ministry of Education, Youth and Sports (MEYS). Professional solutions to the problems in education, problems of optimal use of intellectual and other mental prerequisites for acquiring new knowledge and skills require the closest possible links between the school and psychological science; it focuses mainly on the pedagogical-psychological counselling, educational and career guidance. 
The second counselling system falls under the province of the Ministry of Labour and Social Affairs (MLSA) and provides counselling services especially in the field of career counselling, offers counselling services primarily at employment offices where counsellors and intermediaries provide important services in the Information and Counselling Centres at employment offices. There is also a certain solution in the context of preventive social services. E.g. Šándorová mentions the possibility of participation for social prevention service, early care. This service creates conditions for successful social integration and is carried out mainly in the child's natural environment - in the family (Šándorová, 2005).

The third counselling system is part of the Ministry of Health (MH) and provides counselling services primarily aimed at influencing lifestyles and the health status of the population.

\section{COUNSELLING FACILITIES AND INSTITUTIONS IN THE EDUCATION SECTOR}

There are a number of subjects participating in the current system of educational and psychological counselling within the responsibility of the Ministry of Education: ministerial departments of the Ministry of Education, school counselling facilities and the schools themselves through the school counselling department.

In terms of legislation, the educational and psychological counselling services are enshrined in Act No. 561/2004 Collection of Law, on Preschool, Primary, Secondary, Tertiary Professional and Other Education (Education Act), therefore being an integral part of the educational system.

Basic support in the educational and psychological counselling sphere is provided by the school counselling offices (SCO); the second pillar is formed by the school counselling facilities, i.e. pedagogical and psychological counselling offices (PPCO) and special pedagogical centres (SPC). The counselling facilities also include the educational care centres (ECC), which do not have the status of school counselling facilities - they are part of facilities for institutional or protective care ${ }^{1}$ and act as a preventive educational facility for children with risky behaviour.

At all types of schools, i.e. primary, secondary and higher vocational schools, counselling plays a very important role, implements supporting and assisting activities and thus contributes to the personal growth of students, being instrumental in optimizing the educational process

\footnotetext{
${ }^{1}$ The Czech Republic. MEYS: Act No.109/2002 Collection of Law, on the Execution of Institutional and Protective Education in School Facilities and on Preventive Educational Care in School Facilities.
} 
and preventing and solving problems related to education and upbringing (The Czech Republic. MEYS: Act No.109/2002). The task of the school is to ensure the availability of educational and psychological services in the school itself as well as the necessary quality of those services. High demands and professional pedagogical and psychological skills are required especially from educational counsellors and prevention specialists. Also, teachers are required to acquire new and deeper pedagogical-psychological skills. Schools strive to establish specialized counselling centres in order to create conditions for the early detection of problems in education, conditions for solving teaching and personal problems of students, career counselling and also create conditions for the inclusion of pupils with special educational needs. An important area is prevention of risky behaviour, particularly bullying and various forms of aggressive behaviour, substance abuse and social exclusion. Another very important area, which in the long term is also prevention of insufficient education and long-term unemployment, is career counselling.

Counselling services are not new to the current schools and under the existing law they have been a supportive school system since 2005. However, the changes taking place in the society are reflected in the needs of users of the pedagogical-psychological services. Schools are expected to change the content and organization of the educational and psychological services provided.

A comprehensive change in counselling services has been brought about by the amendment of counselling regulations (Decree No. 72/2005 Collection of Law). Due to the wide range of activities performed by the counselling facilities, the area of the changes is quite extensive and it is not the aim of the paper to describe and give reasons for all the changes. In essence, however, the overall concept of counselling is now evolving from a medical model into a pedagogical model (Homolova, 2013) from determining diagnoses into adjusting the degree of supportive measures. According to Mertin (2013), the problem is that the school system insists on "the paper", i.e. first, it is necessary to determine a diagnosis and then we can work with the child differently. Philosophy of change aims to individualize school work, which means that first the teacher has to help himself/herself. Only if he/she fails to find a good way after repeated efforts, he/she turns to the experts. This brings with it greater demands on teachers themselves and on the expertise of the school counselling staff when the rapid assistance by a counselling expert, albeit only through consultation, can help the teacher enormously. The problem is that schools (and counselling staff particularly) are required to perform activities, for which the necessary conditions have not been established. 


\section{SCHOOL COUNSELLING OFFICE}

The school is an environment in which students spend a great deal of time. It is therefore a place familiar to them, and therefore an environment in which they manifest themselves most openly. The school counselling office (SPP) is the designation for a team of counsellors who work with pupils in the school environment and thus have a considerable potential to capture signals that something is wrong with the pupils - and respond in a timely manner. They can work not only on the level of prevention, but by early intervention. They can also significantly affect the progress and development of a number of problems which may not directly threaten the life or health of students, but are quite common (poor school results, problems in relationships, career choice etc.). The school counselling office should serve as a sort of bridge for these pupils. It should encourage an intimate climate within the school, which would enable students to seek help naturally and without being forced to, especially when they should subjectively need it themselves. The schools seek to create a fully functional school counselling office that provides counselling and consulting services for pupils, their legal guardians and teachers. The headmaster or an appointed deputy director is responsible for providing counselling services in the school. The current situation in schools shows that schools are claiming increased demand for educational and psychological services. At most schools, unfortunately, there is only a basic model of the school counselling office, i.e. there is only a guidance counsellor and a school prevention specialist working in the school within their full time employment (Ehlová, 2016).

Based on the Counselling Services Concept (The Czech Republic. MEYS, 2005), the division into full and incomplete counselling offices was introduced where the basic variant (incomplete counselling office) includes a guidance counsellor, school prevention specialist as well as classroom teachers, art and music teachers and a specialized methodology teacher for the preparation of school educational programmes. The extended variant (full school counselling office) supplements the basic variant with a school psychologist and/or school special educator. The fact that there are psychologists working at some schools, especially elementary schools, was initially allowed by economic projects co-financed by the European Social Fund (ESF) and the Czech Republic. All these projects followed one another in terms of time and programme up since 2005. Initially, it was the introduction of the position of school psychologists and school special education teachers, and then the projects were targeted to support the development and methodological guidance of school counselling services. After the completion of the projects, schools must seek means for maintaining the position of the school psychologist and/or the school special education teacher. Whether these positions are staffed by 
the school is decided by the headmaster with particular regard to the economic situation of the school.

Currently, there are guidance counsellors and school prevention specialists working in the field of school counselling at all schools (except for small schools) counsellors, while in exceptional cases, both of these jobs are performed by one teacher. It is thus a basic SCO model. Some schools then complement the services of this teaching staff with services of school psychologists and school special education teachers (mostly in the form of external collaboration or part time jobs). Practice shows that the presence of a school psychologist or a school special education teacher is desirable especially in schools that educate a large number of students from disadvantaged backgrounds and students with special educational needs.

For the SCO to work properly, close cooperation between the counsellors is necessary. At many schools, these offices are passive teams, i.e. the counsellors know about each other, but they do not always communicate with each other when finding solutions to problems, they rarely share information about the steps taken by their colleague, their services overlap, they meet minimally or not at all, rarely communicate with each other, sometimes only by phone or e-mail (Ehlová, 2016). If we want to create an active counselling team of experts, it is necessary for the team members to meet regularly, look for possibilities of solving problems in a managed way, invite pupils and their parents to meetings if need be and consult suggestions for solutions with them.

According to Hellebrandová (2006) the biggest barriers hindering multidisciplinary cooperation or even making it impossible - the different status of the professions, competition between organizations and experts, stereotypes, lack of confidence in the competence of other experts in the team, the unclear roles, lack of cooperation or power interests.

\section{STAFF OF THE SCHOOL COUNSELLING OFFICE}

\section{Guidance counsellor}

Guidance counsellor (GC) is a teacher appointed by the headmaster to perform professional counselling services beyond his/her normal teaching activities. According to the Education Act (The Czech Republic. MEYS: Act No. 561/2004), the guidance counsellor has to work on all primary, secondary and higher vocational schools. With the changes in social needs after 1989, the role of educational advisers transformed as well and their activities today represent a modern counselling service with relatively clearly defined areas of services. With regard to the scope of their activities, the currently used term "guidance counsellor" and 
"educational guidance" feels a bit outdated. The present concept views the guidance counsellor not as someone who guides or provides guidance to parents, but as someone who provides professional assistance to students and their parents in solving problems related to education.

Given his/her daily presence and thus easy availability at school, the guidance counsellor is often the first adult person to whom the student or his parents turn with their problem. The required competence lies in the completion of specialized studies for school counsellors covering 250 hours, which takes place in the context of lifelong learning (Decree No. 317/2005 Collection of Law). The studies emphasize particular disciplines focused on education and school counselling, vocational and career counselling, counselling to support talented and gifted individuals, counselling focused on preventing and dealing with socio-pathological phenomena. Professional erudition also means the ability to work with the school as a system, communicate about students' problems with the school management, with teachers and parents and thereby create a collaborative environment that helps in solving problems of individual students and entire classes. The role of these professionals in the schools is significantly preventive as well as therapeutic and intervention-based. An equally important task of the guidance counsellor is to provide professional career development counselling services, which is followed by specialized services provided by other entities. The aim is to increase the efficiency of the choice of profession in accordance with the possibilities and individual abilities of students so that their choice coincides with societal demands. Career counselling should be seen as a bridge between the worlds of education and work. Above all, cooperation and coordination between the two systems is necessary.

Given that the counsellor provides counselling services in addition to his/her other job (teacher, headmaster, deputy headmaster), the extent of his/her educational activities gets reduced. The weekly extent of counselling services varies according to the number of pupils in the school. The guidance counsellor's weekly extent of direct teaching activities is correspondingly reduced from 1 to 5 hours. The low number of teaching hours of the reduced workload really begs a discussion of whether or not the guidance counsellor has sufficient space to perform quality counselling. The probability that this activity will turn, for reasons of time constraints, into routine administration in the form of, for example, administration of applications for secondary or higher vocational schools and universities and thereby overlays major consulting services is very high.

Due to the low number of lessons, guidance counsellors can do no more than monitor emerging problems, but they do not have space to implement measures and long-term care of pupils. Situations in practice appear to be problematic when headmasters have excessive 
demands on the counsellors' activities, but have only minimal capacities to create adequate labour conditions for them in the school. Also, students' parents have the notion that counsellors are professionals having a special, profound knowledge and effective recipes for every problem. Unfortunately, they often do not accept their fault, expecting positive changes with minimum endeavour. Subsequently, they measure the counsellor's quality using criteria of practical changes and rapid solutions to often complex problems. Such an expected ideal of services shifts the counsellor's role into a sort of a mission that brings with it unrealistic demands on qualification and the amount of time spent, which together with teaching duties breeds high professional workload.

\section{School prevention specialist}

In accordance with the Education Act, the office of school prevention specialist (SPS) is also mandatory in every school. The headmaster appoints a prevention specialist from among the teachers, whose role in implementing effective prevention and anti-drug activities for children and youth in the school is crucial. SPS works primarily in the area of prevention of socially undesirable phenomena. His/her specific tasks include assistance in developing and implementing the programme for the prevention of substance abuse and negative phenomena in the school, innovation of prevention strategies, provision of professional guidance and methodological assistance to teachers with the implementation of the prevention programme, coordination of educational events for teachers, cooperation with institutions that provide professional assistance in the prevention issues, ensuring the awareness of students and parents in the area of prevention as well as care for children who have addiction issues, etc. (Zapletalová, 2010). To be allowed to perform their duties, the school prevention specialists need to have undergone specialized studies within the further education of teachers in the duration of at least 250 teaching hours completed with defence of a final written exam and an examination before the commission.

School prevention specialists also have complicated position as they have no relief for their work from the teaching workload. As is the case of the position of guidance counsellor, it can be assumed that the functionality of the service also depends on personal interest and selfmotivation to engage in preventive work with pupils. In a research study carried out by Procházka (2012), the complex issue of implementation of school prevention programme is described and the results suggest problem situations. Teachers are appointed to this position while usually being "forced", i.e. the survey data clearly confirm the assumption of a formal course of introducing this position in practice. The appointment of school prevention specialist 
is of great significance for the school only if the teacher has space to actively complete the school prevention concept, monitor and evaluate the activities implemented, and observe and innovate the scheduled programme. The school prevention specialist makes it possible for parents and children to find a mentor and expert at the school who is prepared, motivated and able to carry out prevention and help solve problem educational situations (Procházka, 2012).

At school, there are a number of occasions in which guidance counsellors and prevention specialists work closely together and it is mainly a matter of mutual agreement which one of them will take particular actions. It happens in some smaller schools that this function is cumulated and both positions are occupied by the same teacher (Krejčová, 2010). One of the many disadvantages of such cumulation is too many duties arising from both roles and, at the same time, a minimal chance to share and consult the issues arising with someone at the school and then seek solutions.

\section{School psychologist}

Since 1990, there has been a spontaneous demand for school psychologists in the Czech Republic, not only in primary schools, but also in secondary and higher vocational schools. Before 2005, school psychologists worked only rarely in schools, usually they were categorized as teachers or headmasters employed them for several hours in a month and paid them as a service to the school. Their activity was not defined in the legislation, they were not given methodological guidance and neither their education was systematically addressed. For the first time, standard activities of these specialists were defined in 2005 and anchored in Decree No. 72/2005 Collection of Law, on providing counselling services in schools and school counselling facilities. Also, the Concept of Providing Counselling Services in Schools was created (Krejčová, 2010), which characterized the counselling office as a team of experts comprising of a guidance counsellor, prevention specialist, school psychologist and school special education teacher. These efforts leading to anchoring school psychologists and school special education teachers in Czech elementary and secondary schools culminated in the ESF VIP - Career project. School psychologists and special educators thus started working systematically in schools. At each of the schools, there was one, rarely two experts (school psychologist, school special education teacher) who formed part of the school counselling department. The main objective of the project was to bring psychological and special educational services to pupils, their parents and teachers. This project was followed by other projects supporting the school counselling offices at many other schools. Workloads of the 
school psychologist and school special education teacher were co-financed by the European Social Fund and the Czech state budget.

After the completion of projects, schools had to seek means for maintaining the position of the school psychologist and/or school special education teacher. The services of school psychologist may also be provided in cooperation with the counselling psychologist who, at the request of the school, comes to the school only for a few hours a month. In practice, the introduction of school psychologists in schools does not mean that school psychologists substitute the work of educational and psychological counselling offices and counselling psychologists. It is rather a reaction to the increasing prevalence of school problems, causing an increase in the number of clients in the counselling offices. A big advantage of the presence of the school psychologist in the school is timely intervention concerning students with learning difficulties, methodological support to teachers in follow-up care for pupils with specific learning disabilities (SLD) and increased possibility of rapid intervention in emergency situations. By filling the position of school psychologist, it would be possible to reduce the excessive workload of guidance counsellors and other school employees.

\section{School special education teacher}

Another counselling position we often encounter in elementary schools and even more often in special schools is that of the special education teacher. Under the Act on Educational Staff (The Czech Republic. MEYS: Act No. 563/2004), special education teachers are required to have completed the accredited master's Education (Special Education) study programme in the field of Special Education. The special education teacher's role lies in the correction of learning and behavioural disorders and the process of integration of disabled pupils (Zapletalová, 2009). This is how the special education teacher's activities differ from the above-identified guidance counsellors' job description. His/her duties include preparing and influencing the conditions for the integration of children with disabilities, long-term monitoring and regular assessment of the integration process of the child, special educational diagnostic activities, re-education care for pupils with special educational needs (Zapletalová, 2001). Their competence covers students with diverse special needs, whether they attend to them through individual re-education and consultations with parents or in group work in the classroom. The Czech School Inspectorate reports that although the elementary school system seeks inclusion (the number of pupils with special educational needs increases) there is a lack of special education teachers in schools (Czech School Inspectorate, 2018). For example, in the Pardubice Region, a total of 46460 pupils were educated in primary schools in the 2018/2019 school 
year, of whom $981(2.1 \%)$ were in special classes. A total of 6,019 (13.0\%) pupils were educated with special educational needs (The Annual Report of the Czech School Inspectorate for the School Year 2012/2013). Region Also, secondary schools have a long experience in identifying disadvantaged students and those with disabilities, including students with learning disabilities or behavioural disorders. However, in secondary schools, school special education teachers work rather rarely. Schools therefore rely on cooperation with school counselling facilities and together they prepare specific compensatory and support measures, including individual education plans for integrated pupils.

A risk factor is that apprenticeships show increased incidence of pupils with special educational needs and also their specific support is rather rare (only 17\%). While schools have integrated functional systems informing teachers about pupils with special educational needs, including suggested approaches and practices, their own implementation in the classroom is very often only a matter of personal responsibility of individual teachers. Monitoring activities of the managements of conventional secondary schools are only rarely focused in this direction (The Annual Report of the Czech School Inspectorate for the School Year 2012/2013).

\section{RECENT TRANSFORMATIONS OF SCHOOL COUNSELLING SERVICES}

The comprehensive change leading to the professionalization of the school counselling system is not related only to the professional staffing of the counselling department at schools. The current trend is to support pupils with special educational needs (SEN) and incorporate them into mainstream education, i.e. into ordinary schools. The basic activities of the guidance counsellor and tasks of the school counselling department also include supporting these students, creating conditions for their education and development and thereby preventing their segregation in the society. Even though education provides significant specific benefits to students with disabilities, it is usually more difficult to achieve adequate educational levels and choose an appropriate study specialization. When choosing schools, in addition to their limits, students are also faced with many obstacles and barriers arising from wider economic, social and technical conditions. To make sure that these students achieve the highest possible level of knowledge and skills with regard to their personal potential, the main mission of schools is to pay great attention to this group of students, including individual counselling care that can only be ensured within the school by high-quality, professionally functioning school counselling department. 
Currently, considerable attention is focused on documents dealing with the education of pupils with SEN. In recent years, inclusion in education has been an issue not only for professionals, but also on the political scene. For some representatives of political parties, the issue has become a tool for gaining publicity, or for creating appealing gestures, and that is in particular why inclusion is approached rather emotionally than constructively in the societywide scale. Political developments have paralyzed this issue and we are failing to establish a professional discussion for its further development in favour of the society or in favour of the school system of the Czech Republic.

In the recent past, we have seen quite a significant transformation of the educational system in the Czech Republic, which began with the adoption of the new Education Act in 2004 and has steadily continued to this day. As part of these changes, all components of the Czech education system are reconsidering their place and function. Despite all the measures adopted, however, the Czech education system is still sharply criticized for the high degree of segregation in education and the ensuing reproduction of social inequality. This criticism has been heard coming from international and national institutions. The ongoing reform is attempting to remedy that situation, but there is no consensus on which system is best suited for education. Representatives of different opinion factions are not able to find a communication platform for a constructive debate.

Within the elementary education system, the system has long been on the road between segregation and integration, and now it finds itself rather somewhere between integration and inclusion. Not all components of the system are ready for this transition, and therefore there is a paradoxical situation where pro-segregation, pro-integration and pro-inclusion activities of educational institutions are mixed together. In an inclusion-oriented school, pupils are not divided into children with needs and children without them, the disabled and the intact, children with a disability or without it. They are all seen as individuals who show a need to take their personal characteristics into account.

The new Education Act, mentioned above repeatedly, introduced the concept of special educational needs. Particularly problematic was the use of the institute of the so called social disadvantage, especially its absent compensation in schools. In general, this model of defining a pupil with special educational needs has been criticized as a whole. The professional community (e.g. Association of Pedagogical-Psychological Counselling Centres) has repeatedly urged a change in legislation in favour of a concept of multi-level support the pupil is supposed to get. It is no longer relevant why the pupil has certain disadvantages, but what 
kind of support measures he/she is supposed to get. Each category of support, or its level, would then be properly funded.

At present, there is a new document being produced, the Catalogue of Support Measures for students with disabilities and physical handicaps. The Catalogue of Support Measures should serve as a practical guide advising teachers how to work with a child who is failing in the classroom - whether because of his/her physical handicap, mental disability or health or social disadvantage. Every handicap has five levels from the simplest to the one where the student needs entirely individual lessons. Based on this scale, support during the education process is determined. Most of the Catalogue of Support Measures for children with special educational needs has been completed. The Catalogue of Support Measures (Edition 2015) lacks only a separate part focused on supporting pupils with learning disabilities and behaviour. In the future, however, professional and financial opportunities will certainly be found to modularly fine-tune these important-in-practice parts. Based on this guidance material, teachers and counsellors will choose appropriate ways to help children with special educational needs in their inclusion in mainstream schools. The comprehensive manual of the Catalogue of Support Measures has already been introduced in its electronic version, which is now running in trial operation. The Catalogue of Support Measures is internally divided into eight parts that provide pupils with the need for supportive measures, their teachers, but also their parents and other interested parties with an overview of possible means of support in education (Catalogue of Support Measures, 2015-2016).

With the support measures put into practice, which is expected in September 2018, and with the levels of support applied in schools, there will be an increase in demands on communication and cooperation of the entire team school counselling department. It is yet to be seen after it is put into practice whether the new way of support has any actual positive impact in the daily lives of children, parents, teachers and guidance counsellors at the school.

\section{CONCLUSION}

The aim of the school counselling services is to ensure consistency between the requirements of the environment and the capabilities of students and respond to their demands. That implies the dual role of counsellors - on the one hand, to help children develop skills appropriate to their age and, on the other hand, to ensure greater sensitivity of schools and the society in relation to the needs of children. The question remains to what extent the current school is ready to reflect the changing needs of children and respond to these changes. The 
paper mentioned some areas of the school counselling staff's activities that undoubtedly require a considerable amount of work and great expertise. The ideal situation would be a fully professionally represented school counselling office at every school. In this case, the work of its members would be spread out more and many issues would be resolved more easily and quickly in their fine mutual cooperation.

On the other hand, Zapletalová (2013) mentions that there are only a few countries where such an office is in every school. For example, in Israel or England, but also in Austria or Germany, there are substantially fewer of them than the schools. The work of the counselling staff is unquestionably very extensive and the school environment is very dynamic and fast. Therefore, it is necessary to make sure that counselling services are always flexibly adapted to arising conditions. Therefore, it is necessary to implement an effective support system throughout the area of counselling, and the forthcoming legislative or ideological support is not enough. The functionality of counselling services depends largely on the material support that is consistently overlooked in the Czech school system due to insufficient funding of the entire education system.

Regarding inclusion, experience from abroad shows that embedding inclusion into the education system is not just an isolated matter of education and funds. Inclusion efforts are primarily a social matter. Inclusion of children in mainstream schools has an overlap in care of the family, which lies within the responsibility of other ministries as well. We can see a significant multi-application effect in that other issues are also addressed through the education system and, e.g. the issue of equality and social inclusion. In the Czech Republic, inclusion is the first step, and the consistency, perseverance and ingenuity come next. Still, problems cannot be avoided; the difference lies in the willingness to solve them. European countries that set an example in terms of inclusion show a symbiosis of inclusion and the counselling system. After the Norwegian reform in the 1990s, special schools for handicapped students were transformed into counselling centres for teachers in mainstream schools. These centres provide support to schools in the education of students with special needs, which appears to be - and the experience of schools proves it - a very effective method of coping with the transition of the system to another structure (Kartous, 2015). Teachers from originally special schools do not feel to be sacrificed for the reform; on the contrary, they are in the position of expert counsellors. Regular schools and common teachers thus gain valuable support and assistance in adapting to the education of a larger number of pupils with special educational needs so that they are able to meet the children's needs in the best possible way. All components of the system thus profit without having feelings of injustice that resonate, for example, among Czech 
teachers of practical schools out of concern about the future of their jobs and the staff of counselling facilities out of fear of overloading the system.

From the perspective of professionalization of the counselling services, as for the aforementioned changes, it is important that experts in the position of special education teachers or psychologists are present at every school. The comprehensive educationalpsychological process will thus take place at the school the pupil attends, and only if not even strong support for education is successful, additional support comes from outside, i.e. from the supporting pedagogical and psychological apparatus.

\section{REFERENCE LIST}

1. Ehlová, M. (2016) Výchovné poradenství na střednich školách v kontextu současnosti. Pardubice: Univerzita Pardubice. ISBN 978-80-7395-991-3.

2. Catalogue of Support Measures [on-line]. Univerzita Palackého v Olomouci, 20152016. [quoted on June 4, 2016]. Available at: http://katalogpo.upol.cz/.

3. Česká školní inspekce (CSI) [on-line]. Praha: ČŠI, 2018. Available at: http://www.csicr.czl.

4. Hellebrandová, K. - Hanušová, J. (2006) Interdisciplinární spolupráce. Praha: Vzdělávací institut ochrany dětí. ISBN 80-86991-79-2.

5. Homolová, K. (2013) Co se má měnit v poradenství. Učitelské noviny, Vol. 17, pp. 1415. ISSN 0139-5718.

6. Kartous, B. (2015) Skandinávské zkušenosti s inkluzivním vzděláváním [online]. Praha: EDUin. [quoted on June 5, 2016]. Available at: http://www.eduin.cz/wpcontent/uploads/2016/03/Skandin--vsk---zku--enosti-s-inkluzivn--m-vzd--1--v--n-m.pdf.

7. Krejčová, L. (2010) Výchovný poradce a jeho kolegové aneb jak nalézt optimální způsoby spolupráce. Ǩízení školy, 5/2010, ISSN 1214-8679.

8. Mertin, V. (2013) Inkluze bez naplnění nutných podmínek je hazard. Učitelské noviny, Vol. 4, pp. 10-11. ISSN 0139-5718.

9. Novosad, L. (2009) Poradenství pro osoby se zdravotním a sociálním znevýhodněním. Základy a předpoklady dobré poradenské praxe. Praha: Portál. ISBN 978-80-7367-5097. 
10. Procházka, M. (2012) Škola a její autorita v oblasti primární prevence. In Vališová, A. Autorita v edukační a sociální práci. Univerzita Pardubice, pp. 180-186. ISBN 978-807395-507-6.

11. School Inclusion Concept of the Pardubice Region [online]. Pardubice Region, 2018 [quoted on June 12, 2021]. Available at: http://www.inkluzevpraxi.cz/files/SIKK PK fin 20200207.pdf.

12. Šándorová, Z. (2005) Základy komprehenzívní a integrativní speciální pedagogiky raného věku. Hradec Králové: Gaudeamus, 97 p. ISBN 80-7041-259-X.

13. The Annual Report of the Czech School Inspectorate for the School Year 2012/2013 [online]. ČS̆I, 2012 [quoted on November 12, 2013]. Available at: http://www.csicr.cz/getattachment/e1b96137-2102-4a87-8cae-7384d9dba60c.

14. Zapletalová, J., et al. (2009) Analýza poradenských služeb ve školských poradenských zařizeních a školách Ref. No. 5850/2009-6/IPPP approved by the Ministry of Education in March 2009 [online]. NÚV [quoted on September 14, 2009]. Available at: http://www.ippp.cz/index.php?option=com content\&view=article\&id=18\&Itemid=77.

15. Zapletalová, J. a kol. (2001) Metodika práce školních psychologů na ZŠ a SŠ. [online]. IPPP [quoted on December 6, 2012]. Available at: http://www.ippp.cz/.

16. Zapletalová, J. (2013) Standardy v poradenství. Učitelské noviny, Vol. 20, pp. 14-15. ISSN 0139-5718.

17. Zapletalová, J. (2010) Školní poradenské pracoviště. In: MIOVSKÝ, M. (eds.). Primárni prevence rizikového chováni ve školství. Praha: TOGGA. ISBN 978-8087258-47-7.

\section{LEGISLATION}

1. The Czech Republic. MEYS: Act No. 561/2004 Collection of Law, on Preschool, Primary, Secondary, Tertiary Professional and Other Education (Education Act).

2. The Czech Republic. MEYS: Act No. 563/2004 Collection of Law, on Pedagogical Staff.

3. The Czech Republic. MEYS: Decree No. 72/2005 Collection of Law, on Providing Counselling Services in Schools and School Counselling Facilities.

4. The Czech Republic. MEYS: Decree No. 27/2016 Collection of Law, on the Education of Children, Pupils and Students with Special Educational Needs and Children, Pupils and Students Exceptionally Gifted. 
5. The Czech Republic. MEYS: Act No.109/2002 Collection of Law, on the Execution of Institutional and Protective Education in School Facilities and on Preventive Educational Care in School Facilities.

6. The Czech Republic. MEYS: Decree No. 317/2005 Collection of Law, on the Training of Pedagogical Staff, Accreditation Commission and Career System of Pedagogical Staff.

7. The Czech Republic. MEYS: Concept of Counselling Services Provided at the School. Ref. No. 27 317/2004-24. In: MEYS Bulletin, 7/2005.

Copyright (C) 2022 Published by Khachatur Abovyan Armenian State Pedagogical University \& the Authors

The article submitted and sent to review: 10.08 .2021

Accepted for publication: 18.01.2022 